\title{
MRS Council Examines Progress, Charts Goals
}

\section{Contributions to National MSE Study and International Community Reported; Topical Expansion of Meetings and Journal of Materials Research Foreseen}

\author{
R.C. Ewing \\ 1986 MRS Secretary
} \begin{abstract}
The Council and officers of the Materials
Research Society met December 5-6, 1986 in Boston during the 1986 MRS Fall Meeting. All officers and officers-elect were present, as well as 17 out of the 20 councillors and councillors-elect. The Society is well served by the nearly $100 \%$ attendance of its elected officials. During this meeting many important actions were approved and programs initiated. This is a brief summary of some of these important actions.
\end{abstract}

\section{Treasurer's Report}

Treasurer Clif Draper presented the Treasurer's report (see the September/ October 1986 issue of the MRS BULLETIN, p. 53-54). In the period from November 15, 1985 to November 14,1986 , the total assets of the Society grew from $\$ 727,927$ to $\$ 1,051,621$. The total fund balance is $\$ 989,345$. Total liabilities have decreased slightly to $\$ 62,276$. The Society has sustained this growth at the same time it has initiated a major new project, Journal of $\mathrm{Ma}$ terials Research. The Society's primary sources of income have been corporate sponsors and grants, registration fees, the sale of proceedings volumes (these three activities comprise $73 \%$ of the total revenues), and member dues. The fastest growing source of revenue has been the sale of proceedings volumes. In 1987, the income from the sale of proceedings volumes will surpass income from meeting registration. MRS has also begun to publish conference proceedings from other scientific meetings which are not sponsored by the Society but are of interest to the membership.

Finance Committee Chair Sue Kelso presented the preliminary 1987 budget. Projected 1987 expenses are just over two million dollars; projected income, $\$ 2,136,790$. The Council approved a motion presented by the Finance Committee that $\$ 400,000$ be set aside in a designated fund which can be used to fund the longterm goals of the Society (e.g., purchase of a headquarters building, endowments for special awards, fellowship programs, etc.)

\section{Fall Meeting}

Executive Director John Ballance reviewed the 1986 MRS Fall Meeting. Over 1,400 papers were presented in 22 symposia with a total meeting registration of approximately 2,500 . Although this represents an increase over the previous year, the rate of increase between years has decreased significantly. The Fall Meeting has lost none of its momentum despite successful Spring meetings on the West Coast. Considerable discussion was noted (particularly in the Long Range Planning Committee) about whether this growth requires a change in the format and size of the Society's meetings (e.g., limit the meeting to one hotel, limit the number of symposia, limit the repetition of symposia). These are all questions for which the officers and councillors would appreciate suggestions and opinions from the membership.

\section{MRS Headquarters}

The headquarters continues to grow in response to greater demands (e.g., expansion of the MRS BULLETIN, publication of proceedings volumes, and expanded membership services). In addition to the present ten staff members at headquarters, the Council authorized two additional fulltime, permanent staff members. These positions will be filled in the areas of data processing and editorial activities. Headquarters will take advantage of additional space that is available adjacent to the present offices in order to accommodate the new staff members. John Ballance introduced Regis J. Ebner, Jr., the new financial controller at headquarters. John Ballance emphasized that all members are welcome visitors at the headquarters in Pittsburgh, PA.

\section{Membership}

At present the total membership of the Materials Research Society stands at 4,789. Of these members, 648 are student members and 819 are foreign members. This compares to a membership of 3,540 in 1985. Council approved the petition of the Delaware Valley Section which joins six other active regional sections. The Council approved the petition from the University of Wisconsin-Madison for the creation of a student chapter. There are now ten MRS student chapters. In order to expand student benefits, the Council expanded the short course scholarship program to include qualified undergraduates.

\section{Journal of Materials Research}

Journal of Materials Research was successfully launched in 1986. During its first year nearly 900 pages were published, and over 400 institutions subscribed. The Editor-in-
Chief, Charles Duke, who deserves much of the credit for this first year of success, found it necessary to resign his position. The editorial office for $J M R$ was therefore moved to the MRS headquarters in Pittsburgh and Linda A. Krysinski joined the staff as editorial office supervisor. Walter L. Brown, AT\&T Bell Laboratories, was appointed the new Editor-in-Chief. There was considerable discussion of continued efforts to solicit manuscripts for $J M R$. Every member should assume responsibility for submitting manuscripts in the widest possible range of topics in materials research. The best way to insure the success of $J M R$ is that the entire membership submit their best papers.

\section{International}

The Society continues to expand its international activities. R.P.H. Chang reported that MRS and the Japanese Society of Applied Physics will cosponsor the IBMM/EM meeting in Tokyo (June 12-17) and a meeting on Advanced Materials (12 symposia) in Tokyo (May 30-June 3 ). Having been legally chartered, European MRS continues to grow and completed a very successful meeting in Strasbourg this past June. The next E-MRS meeting with three symposia is scheduled for June 2-5, 1987 in Strasbourg. Additional contacts were made with representatives from China, Australia, Latin America, and India. MRS has become a model for groups in other countries, and the Council endorsed continued efforts to foster international cooperation.

\section{Long Range Planning}

The Long Range Planning Committee presented a statement of the mission and objectives of the Materials Research Society. After discussion and minor amendments the statement was approved. The mission statement is as follows: "The Materials Research Society is a membership society for the research community working in the materials area. The central mission of the Materials Research Society is to serve as the primary interdisciplinary forum for professionals involved in materials research and development."

A subcommittee of the Long Range Planning Committee (chaired by Kathleen Taylor) polled officers, committee chairs, and members to identify concerns and establish

Continued 
goals for the Society over the next five years. Their recommendations included:

(1) The Society should decide whether to hold the Spring and Fall meetings at fixed locations or whether to rotate the meeting sites.

(2) MRS needs to develop a way to broaden topical coverage at symposia and to discontinue symposia whose topics have been thoroughly explored (in order to make room for new symposia).

(3) MRS needs to insure that the growth of headquarters staff matches the needs and demands of the Society, but does not outstrip the growth in the membership. This requires careful consideration of staffing needs before the Society enters into new, additional activities.

(4) MRS must increase its impact on universities (e.g., curriculum, textbooks, and student chapters).

(5) Topical coverage in Journal of Materials Research must be expanded.

These are but a few of the recommendations, but they do reflect the careful attention to detail and the discussion of the long term goals of the Society that are characteristic of the Society's committee and Council meetings.

New procedures were approved for selecting the Von Hippel Award recipient. Nominations will be made to a select committee of five MRS members. This committee will present a rank-ordered list of the three top candidates, with welldocumented recommendations, to Council. The committee can recommend that no award be made. The final selection will be made by Council vote. These changes were made to insure that nomination materials are well prepared and to lessen the possibility that distinguished materials scientists might be overlooked during the nomination process. In addition, the Von Hippel Award was increased in value to $\$ 5,000$.

\section{Executive Committee Report}

In his Executive Committee report, Gordon Pike noted that the Spring Meeting locations have been confirmed through 1990. They are:

1987 Anaheim, California

1988 Reno, Nevada

1989 San Diego, California

April 21-25

April 5-8

April 24-28

1990 San Francisco, California April 16-20

Gordon Pike also reported that the MRS application to become an Associate Member society of the American Institute of Physics has not been accepted, although MRS was encouraged to apply for full member status and was invited to send a nonvoting participant to the next three board meetings for the purpose of redefining the MRS-AIP relationship.

MRS sponsored the Forum on the Materials Science and Engineering Study during the 1986 Fall Meeting as a way to respond to a request for input to the National $\mathrm{Re}$ search Council's Materials Science and Engineering Study. Over 30 papers were received and published as a book titled Communications on the Materials Science and Engineering Study. With the Communications book and the forum, MRS was the first society to provide substantive input to the NRC study.

These are only a few of the highlights of an active and diverse Society. My two-year term as Secretary for the Society ended in December 1986. It has been an exciting two years in which I have learned that no goal is out of reach of this Society. I have never been associated with a more energetic or devoted group of thoroughly enjoyable people.

\section{MRS BULLETIN}

\section{Covers the Significant Developments and Trends in Materials Research}

\author{
Bring the significant developments at your \\ institution to the attention of your \\ colleagues around the world. Ask your \\ public relations or public affairs \\ department to send information for \\ inclusion in the BULLETIN to:
}

\author{
Editor, MRS BULLETIN \\ 9800 McKnight Road, Suite 327 \\ Pittsburgh, PA 15237 \\ Telephone (412) 367-3036
}

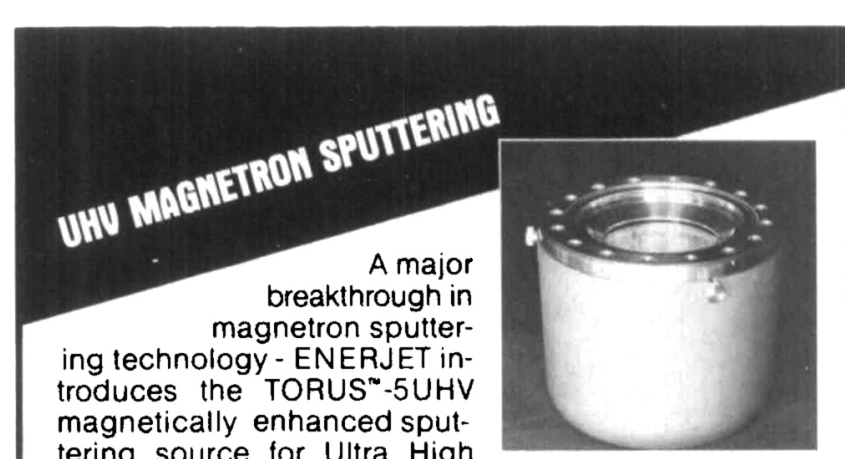
tering source for Ultra High Vacuum applications.

The TORUS" -5 UHV features patented samarium-cobalt magnetic enhancement to create an extremely uniform plasma above the target surface. The high rate resultant films are uniform in nature, homogeneous, small grained, high density, with high specular reflectivity and free of radiation damage and broken bonds. The unique design allows mounting of the source to any UHV system requiring only a standard metal-seal flange. The easily demountable magnet assembly permits fuli UHV bakeout leaving only the target surface within the working environment.

The TORUS" -5 UHV is available for retrofit, new construction, or O.E.M. applications. Contact your local Kurt J. Lesker Company Sales Engineer to discuss your particular application.

\section{ENEAJET}

1515 Worthington Avenue Clairton, PA 15025 (412) 233.2888 (800) $245 \cdot 1656$ In PA: $(800) 242 \cdot 0599$

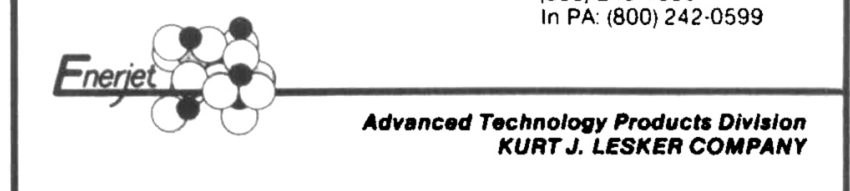

